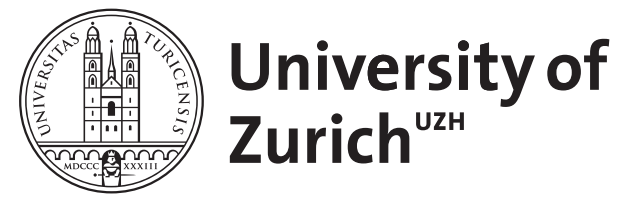
Archive

University of Zurich

University Library

Strickhofstrasse 39

CH-8057 Zurich

www.zora.uzh.ch

Year: 2011

\title{
Business enterprises in public international law: the case for an international code on corporate responsibility
}

Heinemann, Andreas

DOI: https://doi.org/10.1093/acprof:oso/9780199588817.003.0045

Posted at the Zurich Open Repository and Archive, University of Zurich ZORA URL: https://doi.org/10.5167/uzh-53712

Book Section

Originally published at:

Heinemann, Andreas (2011). Business enterprises in public international law: the case for an international code on corporate responsibility. In: Fastenrath, Ulrich; et al. From bilateralism to community interest: essays in honour of judge Bruno Simma. New York: Oxford University Press, 718-735.

DOI: https://doi.org/10.1093/acprof:oso/9780199588817.003.0045 


\section{Business Enterprises in Public International Law: The Case for an International Code on Corporate Responsibility}

\section{Andreas Heinemann}

\section{Introduction}

The most famous anecdote on business ethics is ascribed to Karl Kraus. To a student asking him for his opinion, he answered: 'You want to study business ethics? You have to make a choice: business or ethics!'. The relationship between the pursuit of profit and the respect of ethical values is at the centre of the international activities of firms. Whenever they are active abroad, there are two types of risk, which are under-regulation and over-regulation. On the one hand, companies may come into a legal vacuum, if neither the home nor the host country is willing or able to apply its rules, or if rules applicable to the activity in question do not exist at all. Firms may exploit this vacuum by taking advantage of low labour, health, environmental, tax, or consumer protection standards. On the other hand, it may occur that two or more countries apply their rules simultaneously. In this case, the company may be subject to an excessive burden. In the worst case, the authorities of different countries may impose administrative decisions which are contradictory.

These problems cannot be solved by domestic legislation alone. Of course, it is possible for a State to extend the geographic scope of its regulations in order to cure under-regulation (provided that the jurisdictional limits resulting from public international law are respected). However, often it will not be easy to obtain information about facts which have taken place abroad. Furthermore, the extraterritorial application of domestic law will increase the risk of conflicts with other jurisdictions. Moreover, the interest of political institutions in regulating behaviour of domestic firms abroad may be limited. Hence, there is an urgent need of international coordination in order to overcome the problems raised by trans-border business. The general verdict applies that trans-border problems can only be solved internationally.

The following remarks will focus on the attention which transnational corporations have attracted in public international law over recent decades. The starting point is the world of the Codes of Conduct in the 1970s and 1980s, followed by the experience with the United Nations (UN) Global Compact in the broader context of Corporate Social Responsibility, and the work of the Special Representative of the Secretary-General on Business and Human Rights, before a proposal for an International Code on Corporate Responsibility is submitted. The article is written not only in honour of a pre-eminent scholar who has tremendous merits 
in the development of international law, but also for a teacher and mentor to me. One of the inspirations originating from the legendary atmosphere at his Munich chair led to an article on the non-binding rules for international economic activities. ${ }^{1}$ Twelve years later, the time has come to analyze the important developments that have taken place since then. We will see that the status of business enterprises has changed so that some defend the idea that they have developed from mere objects to subjects of public international law. Be that as it may, the topic is a perfect example for a phenomenon that Bruno Simma - in a different context - has called 'the great shades of nuance that permeate international law'.2

\section{UN Codes of Conduct}

The awareness of governance gaps in the international economy is not new. ${ }^{3}$ In the 1960 s and 1970s a comprehensive framework was aimed at in order to fill these gaps. It was the time of the New International Economic Order. The Charter of Economic Rights and Duties of States (1974) established rules on the economic relations between States based on the principle of national sovereignty. As rights and duties of States were at the centre of the Charter, the behaviour of firms was only touched upon at the edge. Further obligations of corporations were elaborated in a couple of UN Codes of Conduct. ${ }^{4}$ Some of them were formally adopted by the competent bodies and thus gained the status of soft law. Others have stayed drafts discussed during decades. Examples of texts which have been adopted are the Tripartite Declaration of Principles Concerning Multinational Enterprises and Social Policy (International Labour Organization (ILO), 1977), the Set of Multilaterally Agreed Equitable Principles and Rules for the Control of Restrictive Business Practices (UN General Assembly, 1980), the Infant Formula Code (World Health Organization, 1981) and the Pesticides Code (Food and Agriculture Organization, 1985). ${ }^{5}$ The most well-known failures are the Code on

\footnotetext{
${ }^{1}$ B Simma and A Heinemann, 'Codes of Conduct' in W Korff et al (eds), Handbuch der Wirtschaftsethik Vol 2: Ethik wirtschaftlicher Ordnungen (Gütersloher Verlagshaus, 1999).

${ }^{2}$ Accordance with International Law of the Unilateral Declaration of Independence in Respect of Kosovo (Advisory Opinion) 2010 (Declaration of Judge Simma, no 9) <http://www.icj-cij.org/homepage/pdf/ 20100722_KOS.pdf> accessed 28 July 2010.

${ }^{3}$ See H Keller, 'Codes of Conduct and their Implementation: the Question of Legitimacy' in R Wolfrum and V Röben (eds), Legitimacy in International Law (Berlin: Springer, 2008); D Thürer, 'Montesquieu, Smith, Rousseau: Staats- und völkerrechtliche Gedanken zur Einbindung wirtschaftlicher Macht' in D Thürer, Völkerrecht als Fortschritt und Chance - Grundidee Gerechtigkeit, Band 2 (Dike, 2009).

${ }^{4}$ Even though the majority of these texts are of a non-binding hortatory nature, they have or may have legal implications, see D Kinley and R Chambers, 'The UN Human Rights Norms for Corporations: The Private Implications of Public International Law’ (2006) 6 Human Rights L Rev 447, 483-488.

${ }^{5}$ For a detailed analysis see Simma and Heinemann, 'Codes of Conduct' (n 1).
} 
the Transfer of Technology and the Code of Conduct on Transnational Corporations. The breaking off of negotiations for the latter text in 1992 marks the end of the era of UN Codes of Conduct.

Nowadays, some aspects of the New International Economic Order programme seem outdated, such as the assumption of an insurmountable conflict of interest between developing countries and transnational corporations, or the claims for a redistribution of wealth from the North to the South. Instead, there is a growing recognition that economic exchange is beneficial for all sides if the regulatory framework is adequately designed. The term 'Code of Conduct' has changed its meaning. Since the 1990s, it is preponderantly used for private codes of conduct instead for the international texts adopted within the UN family. Private codes of conduct are adopted by single firms (and nearly every big firm has such a text today) or sector-wide, such as the $4 C$ Code of Conduct (coffee sector) or the Voluntary Principles on Security and Human Rights (extractive sector).

The most active forum of the 'old' world of public Codes of Conduct is constituted by the Organization for Economic Co-operation and Development (OECD) Guidelines for Multinational Enterprises (1976, last version 2000, currently under revision). In the guidelines, governments recommend that multinational enterprises should respect certain principles and standards in the fields of general policy, disclosure, employment, environment, anti-corruption, competition, taxation, etc. Of particular importance is the implementation procedure: participating States must install National Contact Points (NCPs) which are competent to handle grievances. Thus, a type of individual complaint is introduced which is unusual in the world of codes of conduct. However, NCPs are criticized for their proximity to governments, their lack of resources, and the absence of precise rules. ${ }^{6}$ Moreover, for the NCPs to be competent, the individual case must have an investment nexus, and the corporation in question must originate from an OECD member State or another State adhering to the Guidelines or must have operated in one of these States. Not least because of the nonuniversal character of the OECD Guidelines, a global forum had to be set up.

\footnotetext{
${ }^{6}$ J Ruggie, 'Protect, Respect and Remedy: a Framework for Business and Human Rights' (April 2008) UN Doc $\mathrm{A} / \mathrm{HRC} / 8 / 5,7,26$.
} 


\section{The UN Global Compact and Corporate Social Responsibility}

\section{Historical context}

International economic integration (often described as globalization) has intensified rapidly, especially after the revolutions of 1989. The foundation of the World Trade Organization in 1995 responded to the new situation. At the same time, global awareness of negative effects rose. Private firms increasingly had to justify themselves for business behaviour abroad. In the United States (US), civil actions under the Alien Torts Claim Act were brought against transnational corporations. ${ }^{7}$ In 1996, Burmese farmers sued a US oil company for the violation of human rights in the context of relocation of villages and forced labour due to a pipeline project in Myanmar. ${ }^{8}$ In the same year, the family of Ken Saro-Wiwa brought an action to a US court against Royal Dutch Shell for complicity in violations of human rights, including the judicial hangings of the Ogoni Nine, in the context of oil exploration in the Niger Delta. ${ }^{9}$ Both cases were settled, as often occurs in this field. ${ }^{10}$ Hence, no conclusive findings of the alleged human rights violations have been established. However, the cases make clear that under US law corporations may be held liable for complicity with human rights violations.

In the same period, public protests against different aspects of the growing internationalization became more visible and condensed into the anti-, respectively alterglobalization movement. In this context, the then UN Secretary-General, Kofi Annan, underlined the leading role of private firms in the process of globalization and proposed the creation of a platform whose task would be to assist businesses in developing socially responsible and sustainable policies. As a result, the Global Compact was launched in $2000 .^{11}$

\footnotetext{
${ }^{7}$ See the overview on relevant Alien Torts Claim Act cases by M Koebele, Corporate Responsibility under the Alien Tort Statute (Martinus Nijhoff, 2009); M Schaub, Grundlagen der Regulierung internationaler Unternehmen (Doctoral thesis, University of Zurich, 2010) 5 II 4.

${ }^{8}$ Roe/Doe v Unocal (2002) 395 F 3d 932 (US Court of Appeals 9th Cir).

${ }^{9}$ See, eg, Wiwa v Royal Dutch Petroleum Co (2000) 226 F 3d 88 (US Court of Appeals 2nd Cir) rejecting dismissal based on the forum non conveniens doctrine. A recent example for a claim under the Alien Torts Claim Act is the admission by the US Supreme Court of a lawsuit of Nigerian families against the drug company Pfizer for alleged non-authorized use of new antibiotics on their children, see Pfizer Inc v Abdullahi (2010) $130 \mathrm{~S} \mathrm{Ct}$ 3541 (US Sup Ct).

${ }^{10}$ The majority of (alleged) abuses are situated in the extractive industries (oil, gas and mining), followed by the food and beverages industry, apparel and footwear, and the information and communication technology sector, see J Ruggie, 'Interim Report of the Special Representative of the Secretary-General on the issue of human rights and transnational corporations and other business enterprises' UN Doc E/CN.4/2006/97 (22 February 2006) no 25.

${ }^{11}$ See in detail S von Schorlemer (ed), Praxishandbuch UNO (Berlin: Springer, 2003) 507.
} 


\section{The ten principles and their implementation}

The Global Compact is not a Code of Conduct, but a forum which is supposed to gain private companies' support for the UN goals. It is based on ten principles in the areas of human rights, labour, environment, and anti-corruption. Businesses shall support, within their sphere of influence, the protection of human rights and make sure that they do not participate in violations. The labour standards include the freedom of association and of collective bargaining as well as the prohibition of compulsory labour, child labour, and discrimination. In the environmental field, firms have to apply the precautionary principle and have to be proactive by, for example, supporting environmentally friendly technologies. Finally, they have to work against corruption in all its forms.

The principles are not binding. Instead, participants have to submit annually a Communication on Progress (COP) in which they give an overview of the practical actions taken and the outcome of these actions including measurement. These communications are published on the Global Compact's website. Participants which do not deliver are listed as non-communicating participants. The quality of COPs is quite diverse: everything can be found from a very general two-page text to detailed reports on specific actions taken and their results. Increasingly, COPs are integrated into the companies' general reporting on Corporate Social Responsibility. ${ }^{12}$

One of the sensitive points of corporate responsibility is the extension of accepted principles to the supply chain. The adoption of high standards would not be credible if intermediate products or services are bought from entities which do not respect these standards on their part. The subject has gained in importance with the process of outsourcing, subcontracting, and offshoring to countries with lower productions costs, lower wages, and lower labour and environmental standards. According to the 'sweatshop argument', low wages and bad working conditions are exploited by transnational corporations which disintegrate vertically and dislocate manufacturing as soon as rules are tightened in a certain country. This argument could be countered by a system in which companies voluntarily adhere to minimum standards, for example in the fields of labour law, environment, and human rights. Today, the opinion is wide-spread that procurement is not value-neutral and that social responsibility applies also to the supply chain. However, it is much more difficult and burdensome to

\footnotetext{
${ }^{12}$ See $n 19$ below.
} 
implement legal and ethical standards with respect to firms other than one's own. ${ }^{13}$ Therefore, one of the central topics of the Global Compact is how to improve the respect of the ten principles in supply chains. ${ }^{14}$

Another area of interest is investment: The Global Compact has extended the ten principles to investment practices by drawing the attention of investors to the environmental, social, and governance (ESG) consequences of their decisions. A concrete result are the 'Principles for Responsible Investment' (PRI) developed by an international group of investors, adopted under the auspices of UN Global Compact and United Nations Environment Programme Finance Initiative (UNEP FI), and launched in $2006 .{ }^{15}$ The six principles focus on the importance of ESG issues for investment decisions and provide for a reporting obligation. Each of the principles contains a list of possible actions. The principles aim at reversing an old question: whereas in the past the question was asked if fiduciaries are allowed to practise responsible investment, PRI wants to establish a general commitment to do so. However, it would be naive to say that the financial industry as a whole has already endorsed this concept. Until now, and in spite of its growing importance, the PRI still concern a niche market. ${ }^{16}$

\section{Corporate Social Responsibility}

The Global Compact, with more than 8,000 signatories worldwide (businesses and civil society), is the most prominent initiative in the field of business responsibility worldwide. However, it is only the especially visible part of a general phenomenon which is called Corporate Social Responsibility (CSR). ${ }^{17}$ Many firms today communicate about their behaviour as 'corporate citizens' and publish sustainability or social responsibility reports. Often they do so in the context of the Global Reporting Initiative (GRI) which was founded

\footnotetext{
13 According to Global Compact reporting, only 12 per cent of participating businesses require suppliers to comply with Global Compact standards in order to be accepted as a partner, see 'United Nations Global Compact Annual Review-Anniversary Edition’ (2010) 14.

${ }^{14}$ Cf. UN Global Compact and BSR, 'Supply Chain Sustainability-A Practical Guide for Continuous Improvement' (2010) <http://www.unglobalcompact.org/docs/issues_doc/supply_chain/SupplyChain Rep_spread.pdf> accessed 28 July 2010.

${ }^{15}$ The PRI are available at <http://www.unpri.org/principles> accessed 28 July 2010.

${ }^{16}$ The result of a joined effort by the Global Compact and PRI is the joint publication 'Guidance on Responsible Business in Conflict-Affected and High-Risk Areas: A Resource for Companies and Investors' (2010) <http://www.unglobalcompact.org/docs/issues_doc/Peace_and_Business/Guidance_RB.pdf> accessed 28 July 2010 .

${ }^{17}$ See, eg, A Scherer and G Palazzo (eds), Handbook of Research on Global Corporate Citizenship (Edward Elgar, 2008); J Zerk, Multinationals and Corporate Social Responsibility. Limitations and Opportunities in International Law (Cambridge University Press, 2006).
} 
by private actors in collaboration with UNEP. GRI has published reporting guidelines which are used by a growing number of businesses and non-businesses and which are refined continuously. The goal of GRI is to establish social reporting as a complement to financial reporting. ${ }^{18}$ There is a close link to the Global Compact: its rules encourage integrating COPs into existing texts like corporate responsibility or sustainability reports. ${ }^{19}$ Thus, it is possible to avoid duplication of work and to bundle CSR-activities. ${ }^{20}$ The most common names are 'CSR Report' or 'Sustainability Report', but there are also individual terms like 'Citizenship Report' or 'Report to Society'. GRI gives ratings on the quality of reports.

The idea underlying CSR is that of a company which not only pursues economic goals, but that takes into account the impact of its activities on all spheres of public life. ${ }^{21}$ Closely linked to the concept of CSR is the distinction between shareholder value and stakeholder value. Another trait is the so-called 'triple bottom line' which complements a purely economic way of measuring success by an ecological and social component. ${ }^{22}$ Many companies today have texts in which they incur commitments in this area. The headings differ, but generally codes of ethics refer to non-economic values, codes of conduct give orientation to employees, and codes of practice specify rules for a certain profession. These texts go beyond compliance policies which are restricted to the respect of existing rules whereas CSR codes include voluntary commitments and aim at filling regulatory vacuums. The International Organization for Standardization (ISO) is currently developing ISO 26000 as the standard for CSR activities. ${ }^{\mathrm{i}}$

\footnotetext{
${ }^{18}$ It is questionable if the distinction between these two kinds of reporting should be upheld in the long run. Concerning environment, the problem of negative externalities can only be solved if the use or the degradation of the environment including climate and biodiversity will be assessed in financial terms and integrated into financial reporting. The 'invisible hand' cannot work where prices are invisible themselves. As regards human rights, risks due to violations should be equally be integrated into financial reporting.

${ }^{19}$ See no 4.1 of the Global Compact's Policy on COPs: 'To avoid duplication of efforts, a COP should be fully integrated in existing stakeholder communications, such as annual, corporate responsibility or sustainability reports'.

${ }^{20}$ Meanwhile, cooperation between the Global Compact and GRI has been formalized by a Memorandum of Understanding signed on 28 May 2010: GRI will integrate the Global Compact's ten principles in the next version of its reporting guidelines, the Global Compact will adopt the GRI guidelines as the recommended reporting framework.

${ }^{21}$ CSR has to be distinguished from philanthropy practiced outside the operative business. Cf TH Moran, 'The UN And Transnational Corporations: From Code of Conduct to Global Compact' (2009) 18 Transnational Corporations 91, 106: 'The principal input—good or bad — that [transnational corporations] can provide to host countries comes from their core operations, not from their philanthropy'.

${ }^{22}$ The three pillars are people (social), planet (ecological), and profit (economic).
} 
The topic has become so important that the European Commission has submitted a report setting the objective for Europe to become a pole of excellence in the field of $\mathrm{CSR}^{23} \mathrm{~A}$ 'European Alliance for CSR' was founded in which, on the one hand, the European Commission undertakes to strengthen a business friendly environment, and where, on the other hand, European companies (large and small) incur the commitment to innovate CSR initiatives further. They do so for example within the European business network 'CSR Europe' which aims at developing CSR best practices for its members. In the 2008 Competitiveness Report, the European Commission analyzed the impact of CSR on different determinants of competitiveness at firm level. The result is that this influence may be positive but that it varies according to sectors and sizes of companies. The contribution of CSR is strongest regarding human resources, risk and reputation management, and innovation. It is less strong (but still existent according to circumstances) in the field of cost structure, the customer perspective, and financial markets. Regarding costs, for example, CSR may benefit a company by attracting motivated employees or by avoiding risks. On the other hand, the additional costs of CSR may outweigh these benefits. The result of this calculation varies according to the different economic sectors. ${ }^{24}$ In sectors which are particularly cost-sensitive, there will be a strong incentive to respect only legally binding rules.

In the European Union (EU), Denmark has gone one step further by adopting legislation on CSR Reporting. Since 2009, large companies have to give information on CSR in the annual financial reports. The mechanism is voluntary: only companies that have CSR policies are subject to the reporting requirements. They may refer to existing sustainability reports. Companies that do not have such a policy and do not want to introduce it, have to state in their report that they do not have a CSR policy. ${ }^{25}$

\footnotetext{
${ }^{23}$ European Commission, 'Implementing the Partnership for Growth and Jobs: Making Europe a Pole of Excellence on Corporate Social Responsibility' (Communication, 22 March 2006) COM (2006) 136 final.

${ }^{24}$ European Commission, 'European Competitiveness Report 2008' (Commission Staff Working Document 2008) SEC 2853, see, eg, 5.4.2.

${ }^{25}$ For further information see <http://www.csrgov.dk> accessed 28 July 2010. As companies are not obliged to give reasons for the absence of a CSR policy, the system does not follow the principle 'comply or explain'. However, the obligation to create transparency puts a certain pressure on the company in this field.
} 


\section{The Special Representative of the Secretary-General on Business and Human Rights}

\section{Mandate}

Closely linked to the discussion on the Global Compact and on CSR is the work of the Special Representative of the Secretary-General on Business and Human Rights. ${ }^{26}$ The story of this most recent development started with a failure. In 2003, the Sub-Commission of the former UN Commission on Human Rights adopted norms on the responsibilities of transnational corporations with regard to human rights, for example in the fields of nondiscrimination, security of persons, rights of workers, anti-corruption, consumer protection, and environment. ${ }^{27}$ For this purpose, mechanisms for the implementation of these commitments were established, for example reporting duties and external monitoring. However, the Commission on Human Rights and, subsequently, the UN Economic and Social Council (ECOSOC) did not embrace the proposal of the Sub-Commission. ${ }^{28}$ Thereupon, the UN High Commissioner on Human Rights delivered a report including a description of existing initiatives and standards on business and human rights. ${ }^{29}$ She concluded that numerous issues required further study. In response to the High Commissioner's recommendations, the Commission on Human Rights requested the UN Secretary-General to appoint a special representative on the issue of human rights and transnational corporations. ${ }^{30}$ This request was accommodated by the appointment of John Ruggie as the Special Representative of the Secretary-General on Human Rights and Transnational Corporations and Other Business Enterprises in 2005. In 2008, his mandate was extended until 2011.

\footnotetext{
${ }^{26}$ For a comparison of the different approaches see S MacLeod, 'Reconciling Regulatory Approaches to Corporate Social Responsibility: The European Union, OECD and United Nations Compared' (2007) 13 Eur Public L 671.

27 Sub-Commission on the Promotion and Protection of Human Rights, 'Norms on the responsibilities of transnational corporations and other business enterprises with regard to human rights' UN Doc E/CN.4/Sub.2/2003/12/Rev.2 (26 August 2003); 'Commentary on the Norms on the responsibilities of transnational corporations and other business enterprises with regard to human rights' UN Doc E/CN.4/Sub.2/2003/38/Rev.2 (26 August 2003). On these texts see Kinley and Chambers, 'The UN Human Rights Norms for Corporations' (n 4); K Nowrot, Die UN-Norms on the Responsibility of Transnational Corporations and Other Business Enterprises with Regard to Human Rights (University Halle-Wittenberg, 2003); D Weissbrodt and M Kruger, 'Human Rights Responsibilities of Businesses as Non-State Actors' in P Alston (ed), Non-State Actors and Human Rights (Oxford University Press, 2005).

${ }^{28}$ ECOSOC_Res 2004/279, 'Responsibilities of transnational corporations and related business enterprises with regard to human rights' (22 July 2004). For the reasons see J Ruggie, 'Business and human rights: Towards operationalizing the "protect, respect and remedy" framework' UN Doc A/HRC/11/13 (22 April 2009), no 58: the draft norms 'so co-mingled the respective responsibilities of States and companies that it was difficult if not impossible to disentangle the two'. One could add another reason: the UN norms were the first non-voluntary initiative in CSR and hence met with strong resistance.

${ }^{29}$ UNHCHR 'Report on the responsibilities of transnational corporations and related business enterprises with regard to human rights’ UN Doc E/CN.4/2005/91 (15 February 2005).

${ }^{30}$ UNCHR 'Res 69' (2005) UN Doc E/CN.4/RES/2005/69.
} 
The terms of reference of the Special Representative do not overlap completely with the subject of CSR. On the one hand, his field of work is human rights, not the protection of the environment or the other areas mentioned above, at least not as such. ${ }^{31}$ On the other hand, his mandate goes further as he has to put human rights into a general perspective not restricted to firm behaviour. During his first mandate (2005-08), the Special Representative developed a general policy framework on the subject of business and human rights. His second mandate (2008-11) aims at operationalizing this approach in order to provide specific guidance to public and private actors.

\section{The protect, respect, and remedy framework}

The general framework is based on three core principles, 'the State duty to protect against human rights abuses by third parties, including business; the corporate responsibility to respect human rights; and the need for more effective access to remedies' ${ }^{32}$ This concept has been accepted equally by business associations and human rights organizations because it strikes a balance between responsibilities of States and private actors. At the same time, it underlines the necessity for victims to have effective remedies, judicial and non-judicial. It is the clear goal of this 'principled pragmatism' to achieve concrete progress in the daily lives of people and to leave behind the ideological clashes of the 1970s and 1980s.

As regards the first principle, States in the first place have to refrain from violating human rights. But they have positive obligations, too. Article 2(1) of the International Covenant on Civil and Political Rights, for example, not only obliges a State to respect fundamental rights, but also 'to ensure to all individuals within its territory and subject to its jurisdiction the rights recognized in the present Covenant'. This includes the obligation for States to take active measures in order to protect right holders against interference from private actors including businesses. ${ }^{33}$ Only if the State undertakes all reasonable measures to be expected according to circumstances, will corporate interference not be imputed to the State in question (standard of conduct versus standard of result). For example, a State has to prohibit corporate abuse by

\footnotetext{
${ }^{31}$ In the field of human rights, there are close links between the Global Compact and the work of the Special Representative, see, eg, Global Compact, 'Guide on How to Develop a Human Rights Policy' (2010) <http://www.unglobalcompact.org/docs/issues_doc/human_rights/Resources/How_to_Develop_a_Human_Right S_Policy.pdf $>$ accessed 28 July 2010.

${ }^{32}$ Ruggie, 'Protect, Respect and Remedy' (n 6) 1.

${ }^{33}$ See the comprehensive analysis of relevant international treaties in J Ruggie, 'State responsibilities to regulate and adjudicate corporate activities under the United Nations core human rights treaties: an overview of treaty body commentaries' UN Doc A/HRC/4/35/Add.1 (13 February 2007).
} 
law, to investigate alleged violations, to bring perpetrators to justice, and to grant effective remedies to victims. ${ }^{34}$ It is clear that these principles apply to acts within the territory of the State in question. It is one of the most difficult and most debated questions if and to what extent States are responsible for preventing abuses abroad. ${ }^{35}$ The Special Representative is rather cautious in this respect, ${ }^{36}$ but he points to the options States have in this respect, for example human rights conditionalities in public procurement, export credit guarantees, and public insurance of foreign investments. ${ }^{37}$

The second principle is a novelty and concerns the relevance of human rights for businesses themselves. Contrary to the duty of States to protect human rights, the policy framework of the Special Representative uses with regard to corporations the term 'responsibility to respect' ${ }^{38}$ The underlying idea is that, according to traditional opinion, international human rights do not impose obligations directly on companies. Such obligations occur only if domestic law evolves in this sense. However, the international practice expressed by the Global Compact as well as soft law instruments like the ILO Tripartite Declaration and the OECD Guidelines underline the responsibility of companies with regard to human rights. Civil society carefully observes compliance with this responsibility. ${ }^{39}$ The Special Representative has summarized this development by saying that in addition to the legal licence to operate, the success of a company depends also on a 'social licence to operate'. ${ }^{40}$ Firms must not only avoid the infringement of rights ('do no harm'), but they have also to address abuse committed by others. For this purpose, the Special Representative has proposed that companies introduce a human rights due diligence consisting of a human rights policy, an impact assessment, the creation of an integrated human rights corporate culture, and

\footnotetext{
${ }^{34}$ Ibid, 21 et seq.

35 For a summary of the current discussion see A Weber, 'Die rechtliche und politische Dimension von extraterritorialen Staatenpflichten bei Menschenrechtsverstößen durch transnationale Konzerne. Ein Literaturbericht' (2009) <http://www.humanrights-business.org/files/literaturbericht.pdf> accessed 28 July 2010.

${ }^{36}$ Ruggie, 'Business and human rights' (n 28) no 15.

${ }^{37}$ Ruggie, 'Business and Human Rights: Further steps toward the operationalization of the "protect, respect and remedy” framework' UN Doc A/HRC/14/27 (9 April 2010) nos 46-50.

${ }^{38}$ The 'Responsibility to Protect' concept is known originally from the discussion on humanitarian interventions. It gives reasons for an obligation to protect the citizens of another State if this State is not able or willing to protect its citizens itself, see International Commission on Intervention and State Sovereignty, 'The Responsibility to Protect' (Ottawa 2001) < http://www.iciss.ca/pdf/Commission-Report.pdf> accessed 28 July 2010 .

${ }^{39}$ A prominent platform is the documentation of the Business and Human Rights Centre on the positive and negative impact of firm conduct on human rights at <http://www.business-humanrights.org> accessed $28 \mathrm{July}$ 2010 .

${ }^{40}$ Ruggie, 'Business and human rights' (n 28) no 46.
} 
systematic reporting on these subjects. ${ }^{41}$ The Special Representative underlines the fact that company behaviour may have an impact on all existing human rights, not only on those related to the economy. ${ }^{42}$ The basic texts are the Universal Declaration of Human Rights, the International Covenant on Civil and Political Rights, the International Covenant on Economic, Social and Cultural Rights, ${ }^{43}$ and the ILO core conventions. As these texts are in essence State-related, they have to be 'translated' into behavioural standards for businesses. ${ }^{44}$ Corporations do not carry the same responsibilities States have. ${ }^{45}$ The work of the Special Representative is characterized by the attempt not to exaggerate the expectations towards businesses in this field.

According to the third principle of the general framework, victims of human rights violations must have access to effective remedies. At the company level, grievance mechanisms have to be constituted. At State level, judicial remedies must be created which may be complemented by non-judicial mechanisms, for example national human rights institutions or the NCPs provided for by the OECD Guidelines. Other forms of redress are imaginable. ${ }^{46}$

\section{Outlook}

Whereas the Global Compact has brought together private companies and the UN, the aspirations of the Special Representative are broader in that he strives for a comprehensive framework defining the respective tasks of States and private actors in the field of human rights. The more general approach makes it possible for all determinants to be taken into consideration which hitherto were separated from one another. For example, bilateral investment treaties have turned out to have a great impact on human rights matters. As they often have not been coordinated with human rights concerns, tensions arise, for example

\footnotetext{
${ }^{41}$ Ruggie, 'Protect, Respect and Remedy’ (n 6) nos 56-64.

42 J Ruggie, 'Corporations and human rights: a survey of the scope and patterns of alleged corporate-related human rights abuse' UN Doc A/HRC/8/5/Add.2 (23 May 2008).

${ }^{43}$ See B Simma, 'Die internationale Kontrolle des VN-Paktes über wirtschaftliche, soziale und kulturelle Rechte: neue Entwicklungen’ in U Beyerlin et al (eds), Festschrift für Rudolf Bernhardt (Springer, 1995).

${ }^{44}$ See the much cited text of the Office of the High Commissioner for Human Rights (together with Global Compact and others), 'Human Rights Translated-A Business Reference Guide' (2008) <http://www.ohchr.org/Documents/Publications/Human\%20Rights\%20Translated_web.pdf> accessed 28 July 2010.

45 Contrary to frequent criticism against the 'privatizing of human rights', the private responsibility does not reduce but complements human rights duties of the State.

46 See Ruggie, 'Business and Human Rights: Further steps' (n 37) nos 114-16, and the useful database at <http://baseswiki.org/en/Main_Page> accessed 28 July 2010.
} 
regarding stabilization clauses which exempt investors from subsequent public policy measures. ${ }^{47}$ The Special Representative attracts attention to the necessity of integrating human rights aspects as a horizontal aspect in all kinds of international agreements.

Up until now, the Special Representative has submitted highly informative reports on the relationship between business and human rights. However, without the conclusion of a special treaty on corporate responsibility, the legal basis for human rights obligations of private actors stays vague. Therefore, in the absence of new conventional obligations, the work of the Special Representative would only have a legal effect if his guidance had an impact on State practice meeting the high requirements for a change in customary law. It is more realistic to say that the legal consequences of his work will be restricted to modifying the lex mercatoria. $</ p>$

\section{Legal Personality of Transnational Corporations in Public International Law?}

As we have seen, initiatives like the Global Compact or the policy framework of the Special Representative aspire to bridge governance gaps and to integrate businesses into the values of public international law. From a legal point of view, it is important to determine the status of the commitments formed by this development. Even if public international law has started to introduce rights which may be directly invoked by private parties, ${ }^{48}$ obligations normally do not become effective until domestic law has taken them over. ${ }^{49}$ An obligation of undertakings to respect human rights would amount to a direct horizontal effect of these rights, a concept which is far from generally being accepted even in domestic law. Therefore, according to the traditional view, international law does not directly address transnational corporations.

\footnotetext{
${ }^{47}$ Problems could be solved by integrating human rights aspects into bilateral investment treaties, see International Institute for Sustainable Development, IISD Model International Agreement on Investment for Sustainable Development (IISD, 2005).

${ }^{48}$ Examples are individual complaints in international systems for the protection of human rights or investors' rights under the Convention on the Settlement of Investment Disputes between States and Nationals of Other States or under other conventions. For an analysis of recent developments in access of private parties to international dispute settlement mechanisms, see M MacLaren, Rechte, Rechtsmittel und Rechtfertigungen im Völkerrecht. Eine Studie über den Zugang Privater zu internationalen Streitbeilegungsmechanismen (Zürich: Schulthess, 2008).

${ }^{49} \mathrm{~K}$ Weilert, 'Transnationale Unternehmen im rechtsfreien Raum?' (2009) 69 ZaöRV 883, 907. An exception is the responsibility of individuals in international criminal law, cf B Simma and A Paulus, 'The Responsibility of Individuals for Human Rights Abuses in Internal Conflicts: A Positivist View' (1999) 93 American J Intl L 302. There is, however, no general corporate criminal liability as may be illustrated by the fact that the Rome Statute of the International Criminal Court has renounced on an article regarding legal persons. For international humanitarian law see International Committee of the Red Cross (ICRC), Business and International Humanitarian Law. An Introduction to the Rights and Obligations of Business Enterprises under International Humanitarian Law (ICRC, 2005).
} 
Recently, the traditional view has been called in question. There is a debate if non-State actors like corporations may be classified as subjects of international law, and if so, to what extent. In this respect, the core texts for the international protection of human rights may be invoked which refer to non-State actors. ${ }^{50}$ There are scholars who deduce from the influence transnational corporations may have a presumption of legal personality ${ }^{51}$ or infer from existing treaties a partial legal personality. ${ }^{52}$

For our context, this discussion shows that there are no objections in principle against the adoption of a binding international text imposing obligations on businesses in the different fields of CSR. It is not legal personality that determines rights and obligations, but, on the contrary, legal personality follows from the attribution of rights and duties. Therefore, the discussion on the international legal personality of corporations is of secondary importance. However, before dwelling on the topic of binding international instruments, we have to ask the more fundamental question if CSR needs legal rules at all.

\section{CSR between Self-Interest and Altruism}

The subject of CSR touches upon a fundamental question of market economy which is the relationship between self-interest and altruism. Adam Smith had not contented himself with underlining the fundamental importance of self-interest but he had even warned against altruistic behaviour in an economic context: 'By pursuing his own interest, he [every individual] frequently promotes that of the society more effectually than when he really intends to promote it. I have never known much good done by those who affected to trade for the public good. ${ }^{53}$ Following this starting point, Milton Friedman has launched the most

\footnotetext{
${ }^{50}$ According to the preamble of the Universal Declaration of Human Rights 'every individual and every organ of society ... shall strive by teaching and education to promote respect for these rights'. The preambles of both the International Covenant on Economic, Social and Cultural Rights and of the International Covenant on Civil and Political Rights go one step further: 'Realizing that the individual, having duties to other individuals and to the community to which he belongs, is under a responsibility to strive for the promotion and observance of the rights recognized in the present Covenant'.

${ }^{51}$ K Nowrot, 'Transnational Enterprises and Global Public Goods: Towards a Presumption of Normative Responsibilities' in Transnational Economic Law Research Center (ed), Policy Papers on Transnational Economic Law no 1/2004 (Faculty of Law Halle-Wittenberg, 2004).

52 C Hillemanns, Transnationale Unternehmen und Menschenrechte (Doctoral thesis, University of Zurich, 2004) 24-31; Schaub, Grundlagen der Regulierung internationaler Unternehmen (n 7) para 7.

${ }^{53}$ A Smith, An Inquiry into the Nature and Causes of the Wealth of Nations (Straman, 1776), Book IV, ch II. Smith adds: 'It is an affectation, indeed, not very common among merchants, and very few words need be employed in dissuading them from it'. On the other hand, Smith always strived for a balance of self-interest and sympathy. See the first sentence of his Theory of Moral Sentiments (1759): 'How selfish man may be supposed, there are evidently some principles in his nature, which interest him in the fortune of others, and render their happiness necessary to him, though he derives nothing from it except the pleasure of seeing it'.
} 
radical attack against the social responsibility doctrine by saying that 'there is one and only one social responsibility of business - to use its resources and engage in activities designed to increase its profits so long as it stays within the rules of the game, which is to say, engages in open and free competition without deception or fraud, ${ }^{54}$ In this view, investing in CSR is spending someone else's money (in the first place that of the shareholders, but employees and customers may be affected, too) in order to pursue goals which go beyond what is imposed by law.

It is not surprising that the rejoinder to this criticism is based (in part) on the effect of CSR on (long-term) profit. It may be the case that the impact of CSR on the performance is positive. According to a recent adage, 'sound ethics is good business in the long run'. There are more and more studies showing that companies which adhere to environmental and social goals going beyond legal requirements will have a better performance in the long run since, for example, sustainability research may reveal risks hitherto disregarded by traditional financial analysis. Moreover, a clear commitment to social responsibility may be the best way to attract and to retain high potentials. The value of the company's brands may be increased. The only problem that critics like Milton Friedman would have in this situation is that the label of 'social responsibility' for profit-seeking behaviour comes close to 'hypocritical windowdressing, ${ }^{55}$ In the same sense, critics from the other side of the spectrum declare as worthless a concept which uses philanthropic labels for initiatives a company would have taken anyway and which simply allow it to 'greenwash' (environment) or to 'bluewash' (human rights) profit-maximizing strategies. In this view, CSR expressing the enlightened self-interest of a company is useless whereas ethical standards which are contrary to self-interest need binding rules and hence should be transformed into legal norms instead of voluntary standards.

The fundamental question therefore is if and to what extent a private corporation should promote environmental and social goals if this investment does not lead to benefits at least in the long run. In the absence of positive effects, does CSR just cause supplementary costs reducing profits and going against the interests of the firm and market economy in general? The answer should be twofold. In countries with high legal standards in these areas and with a well-functioning rule of law, profit-seeking entities should not be expected to act against their self-interest. Here, the State apparently assumes its task of setting and implementing the rules which satisfactorily promote the public good so that it is sufficient for the companies to

\footnotetext{
${ }^{54}$ M Friedman, 'The Social Responsibility of Business is to Increase its Profits', The New York Times Magazine, 13 September 1970.

${ }^{55}$ Ibid.
} 
comply. ${ }^{56}$ However, in countries where the legal standards are low and/or where the rules are not enforced, companies should on their own initiative respect the rules even though they are not enforced, or practise higher standards where the existing rules are not compatible with the values developed on the international level.

This shows the importance of the Global Compact and of the other initiatives in the field of CSR: an international standard is developed which helps private actors to adopt rules filling in the gaps of the international economy. At the same time, these rules put competitors on an equal footing. It is not acceptable that companies which do not respect the international standards get a comparative advantage because they can produce at lower costs. ${ }^{57}$ In sum, the arguments lead back to the subject of self-interest. With the growing public awareness of the social and environmental impact of corporate behaviour it has become important for companies to incur and to honour commitments in this field. ${ }^{58}$ The relevance will increase rather than wane. The most important question in this context is if it will be sufficient to have a system based on the principle of voluntariness and on the absence of close monitoring or, on the contrary, if we need a legally binding scheme in which States or international organizations set the rules and where companies have to comply.

\section{The Case for an International Code on Corporate Responsibility}

In our view, at this stage, middle ground has to be found. In a first step, the Global Compact should be strengthened. At present, it is non-obligatory in a double sense: a company cannot be forced to join the Global Compact (or other CSR initiatives), ${ }^{59}$ nor are companies-once participating - subject to a strict monitoring procedure. Regarding control, the Global Compact does not interpret its role as that of a regulatory authority. As we have seen, the Global Compact works on the basis of self-reporting: Participants have to report annually. However, the Global Compact does not verify the accuracy of COPs, but relies on the assessment of stakeholders. It confines itself to a platform that develops a framework for responsible business practices. The question may be asked if this approach is not too cautious.

\footnotetext{
${ }^{56}$ It is clear that concepts like 'efficient breach' do not have a place in CSR. Respect of legal rules and contractual obligations is a minimum standard for corporate conduct.

${ }^{57}$ On the other hand, CSR must not itself be used in order to get comparative advantages by raising rivals' costs.

${ }^{58}$ See European Commission, 'European Competitiveness Report 2008' (n 24) 5.5 no 6: 'However, for an increasing number of enterprises in a growing number of industries, CSR is becoming a competitive necessityit is something that they cannot afford not to do'.

${ }^{59}$ In fact, only a low percentage of transnational corporations participate.
} 
Of course, the Global Compact is voluntary. But once companies have agreed to apply the principles and to report on progress, it would be desirable to have some sort of verification. In conformity with the principle of voluntariness, an additional element should be integrated into the Global Compact system: companies that wish to go a step further should have the possibility to accept external auditing in order to control not only the accuracy of their COPs but also the actual contribution of their actions to the implementation of the ten principles. Already, there is the possibility for certain businesses to do more: outstanding COPs qualify for the 'Notable COP programme' and are highlighted especially. External auditing should be added as a further condition for this distinction. Thus, it would be clear that a competent third party examined the information submitted. The standard of auditing could be the consistency requirement of the Danish legislation: ${ }^{60}$ the auditor would have to examine if the information submitted is free of contradictions and consistent with financial reporting of that company.

In a second step, an International Code on Corporate Responsibility should be adopted. It would cover the most important fields of CSR mentioned above and could-in accordance with the heritage of the UN Codes of Conduct of the 1970s and 1980s - be adopted as a resolution of the UN General Assembly. The Code would refine the ten principles of the Global Compact (which seem too unspecific) by building on the OECD Guidelines, the UN Human Rights Norms for Corporations and the work of the Special Representative, and thus give clearer guidance on the substantive standards. The Code would be implemented under the Global Compact mechanism, ie the principle of voluntariness would be upheld.

This is not satisfactory in the long run, though. It is certainly true that the scope of the CSR minimum standards has to be determined carefully in order to avoid stifling of international competition. However, once these standards have been defined, they should be respected by all firms. Otherwise, companies violating these minimum standards would have unfair competitive advantages. As we have seen, market-oriented instruments in the field of CSR do not work well in all respects. Hence, in a last stage, soft law should turn into hard law by concluding a multilateral treaty. It would oblige the contracting parties to adopt domestic rules applicable to firms subject to their laws or based in their country ${ }^{61}$ including an effective implementation mechanism. Implementation should be subject to a principle of subsidiarity: In the first place, the State in whose territory human rights violations occur is competent to handle complaints. If this State is not a party to the treaty or if it does not fulfil the treaty

\footnotetext{
${ }^{60}$ For the legal situation in Denmark see the text at $\mathrm{n} 25$ above.

${ }^{61}$ For the determination of a corporation's nationality see Schaub, Grundlagen der Regulierung internationaler Unternehmen (n 7) para 8.
} 
obligations, victims should have the right to seek redress in the home State of the company in question. There is no sufficient reason to restrict these rules to transnational corporations; any business behaviour with an international dimension should be covered. In order to avoid overregulation and a 'one size fits all' approach, reporting duties should be based on the principle 'comply or explain' known from the corporate governance world. Small and medium enterprises would have the possibility to renounce on social reporting if they explain why.

Of course, the Code would not exclude the adoption of stricter international rules in selected areas (such as labour, environment, human rights, anti-corruption, antitrust). But it would constitute the cornerstone of a global system of corporate responsibility.

\section{Conclusion}

Recent developments in international economic law bring business and ethics closer together. Public awareness of the impact business behaviour may have on the environment and on human rights has risen. Hence, the market mechanism will often work in favour of the protection of public goods since business enterprises have a self-interest in sustainable business strategies and will respond to new consumer preferences. Certain marketing strategies, like Fairtrade or Eco-Labelling strengthen this effect. On the other hand, ethical consumerism has its limits. It works predominantly for trademarked or luxury goods and niche markets, but less well for cheap products, raw materials, and intermediate products. So, it is relatively easy to take measures against blood diamonds (Kimberley Process) or sports goods produced by child labour. However, ethical purchasing decisions are much less relevant for inhuman labour conditions in a coal mine. Moreover, in a realistic view, customers often say that they are willing to pay a price premium for good social and environmental behaviour of a manufacturer or distributor. But eventually, they do not always act as announced.

This mixed balance shows that it is indispensable to provide for binding minimum standards in the field of CSR filling the regulatory gaps of the globalized world. The proposal made here is the adoption of an International Code on Corporate Responsibility. The Code would have many advantages. Business ethics would be transformed into a regulatory framework thus creating a level playing field without hampering international competition. Acceptance of market economy principles by the population would be strengthened. It cannot be underlined too often, and not only in times characterized by financial and economic crisis, that the trust of the population in private companies is a cornerstone of a market economy. And finally, the Code would cure a grave deficit of international economic law: At present, there are many 
binding rules facilitating market access in favour of private actors. ${ }^{62}$ But there are only few obligations imposed on businesses. ${ }^{63}$ For example, the TRIPs agreement provides for high standards of intellectual property protection. But there is no international treaty on antitrust law imposing limits to business strategies. ${ }^{64}$ One of the most important desiderata of international economic law is the establishment of a balance between rights and duties of business enterprises. Much public criticism, for example coming from the anti- or alterglobalization movement since the late 1990s, seems to originate from the one-sidedness of the legal framework. An International Code on Corporate Responsibility could contribute to establishing a world economic order worthy of the name.

\footnotetext{
${ }^{i}$ See Global Compact, 'An Introduction to Linkages between UN Global Compact Principles and ISO 26000 Core Subjects' (2010), <http://www.unglobalcompact.org/docs/news_events/8.1/UNGC_ISO_DRAFT.pdf> accessed 28 July 2010. For an overview of other principles, guidelines and standards in the field of CSR see <http://www.csrgov.dk/sw51192.asp> accessed 28 July 2010.
}

\footnotetext{
${ }^{62}$ Even if these rules often cannot be invoked directly by private entities. For the necessary qualifications see T Cottier, 'The Judge in International Economic Relations' in M Monti et al (eds), Economic Law and Justice in Times of Globalisation. Festschrift for Carl Baudenbacher (Nomos, 2007).

${ }^{63}$ See, eg, Art 10 Paris Convention for the Protection of Industrial Property prohibiting unfair competition.

${ }^{64}$ For a proposal filling this gap see W Fikentscher and U Immenga (eds), Draft International Antitrust Code (Nomos, 1995).
} 